\title{
Pierwiastki ziem rzadkich w kwaśnych wodach kopalnianych - zarys problematyki
}

\author{
Zdzisław M. Migaszewski ${ }^{1}$, Agnieszka Gałuszka ${ }^{1}$
}
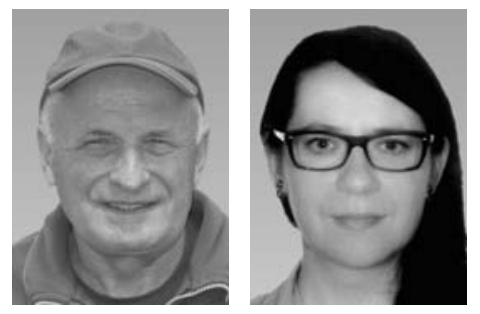

Z.M. Migaszewski A. Gałuszka
Rare earth elements in acid mine drainage waters; an outline of the issues. Prz. Geol., 67: 105-114; doi: 10.7306/2019.2.

A b s tra ct. This paper presents the brief characteristics of rare earth elements (REE) and their occurrence in acid mine drainage (AMD) waters. The special emphasis is laid on REE classification, computation of shale-normalized coefficients and interpretation of REE anomalies. This paper also outlines the REE behavior in the environment, geochemical interactions and their potential application for assessing an impact of AMD on the environment.

Keywords: acid mine drainage, rare earth elements, characteristics, anomalies, occurrence, geochemical interactions
Pierwiastki ziem rzadkich (REE - rare earth elements) należą do tzw. grupy metali krytycznych (critical metals) o kluczowym znaczeniu dla wielu gałęzi przemysłu, a w szczególności elektroniki, hutnictwa, transportu, jak również w coraz większym stopniu dla medycyny i rolnictwa, stąd też w wielu krajach prowadzi się intensywne prace geologiczno-poszukiwawcze celem odkrycia nowych złóż rud tych metali (USGS, 2012; Migaszewski, Gałuszka, 2015). Poza obszarami występowania złóż największą koncentrację pierwiastków ziem rzadkich w środowisku przyrodniczym stwierdzono $\mathrm{w}$ rejonach powstawania kwaśnych wód kopalnianych, na skutek utlenienia pirytu i towarzyszących mu minerałów siarczkowych. Stężenie REE w tych wodach waha się od kilkudziesięciu do kilkuset $\mu \mathrm{g} / \mathrm{l}$, a w niektórych przypadkach osiąga nawet kilkanaście mg/l, w zależności od składu litologiczno-petrograficznego macierzystych formacji skalnych (m.in. Verplanck i in., 2001; Protano, Riccobono, 2002; Bozau i in., 2004; Gammons i in., 2005b; Merten i in., 2007; Romero i in., 2010; Grawunder i in., 2014; Migaszewski i in., 2016, 2019; Lecomte i in., 2017; Soyol-Erdene i in., 2018). Największe stężenie lantanowców (29 mg/l) stwierdzono w wodach podziemnych kopalni uranu w Osamu Utsumi w Brazylii (Miekeley i in., 1992). Przykłady zawartości REE + Y w kwaśnych wodach wybranych kopalń przedstawiono w tabeli 1. Należy wspomnieć, że również inne elementy środowiska przyrodniczego występujące nieopodal takich kopalń (gleby, rośliny) charakteryzują się ekstremalnie dużą zawartością tych pierwiastków, np. liście hiperakumulującego gatunku paproci Dicranopteris dichotoma z rejonu słynnego złoża Bayan Obo w Mongolii Wewnętrznej (północne Chiny), zawierają 3065-3358 mg/kg REE (Wei i in., 2005). Dla porównania, zawartość lantanowców w podbiale pospolitym Tussilago farfara z obszaru Wiśniówki waha się od 16,5 do 28,1 mg/kg (Gałuszka, Migaszewski, 2018). Od wielu lat trwają też badania nad możliwością ekonomicznego odzyskiwania pierwiastków ziem rzadkich z kwaśnych wód kopalnianych, w połączeniu z ich remediacją (Johnson, Hallberg, 2005; Ayora i in., 2016; Pozo i in., 2017).

Badania geochemiczne kwaśnych wód kopalnianych autorzy rozpoczęli w 2001 r. w USA - w rejonie dawnej eksploatacji złóż złota, srebra, miedzi i ołowiu w kalderze zlokalizowanej między Silverton i Ouray w SW części Kolorado (ryc. 1A-D). Współpraca ze Służbą Geologiczną USA z Denver zaowocowała przygotowaniem nowej metodyki badań REE, która następnie została przetestowana i rozwinięta na obszarach historycznej i współczesnej eksploatacji górniczej w Wiśniówce i Rudkach (składowisko odpadów pogórniczych w Serwisie) w Górach Świętokrzyskich (m.in. Migaszewski i in., 2015, 2016, 2018a, b, 2019).

W tym krótkim artykule przeglądowym opisano zagadnienia związane z warunkami powstawania kwaśnych wód kopalnianych, klasyfikacją geochemiczną pierwiastków ziem rzadkich, metodyką ich badań oraz interpretacją anomalii geochemicznych tych metali, pochodzących z interakcji między wodą i minerałami. Celem tej pracy jest również naświetlenie pewnych nieścisłości i nieporozumień, które można odnaleźć w literaturze geologicznej dotyczącej przedmiotowego zagadnienia. Autorzy przytaczają też liczne przykłady z rejonu Wiśniówki, który należy do obszarów powstawania unikatowych w skali światowej kwaśnych wód kopalnianych i obok Rio Tinto stosunkowo najlepiej pod tym względem rozpoznanych.

\section{ŚRODOWISKA WYSTECPOWANIA KWAŚNYCH WÓD KOPALNIANYCH}

Kwaśne wody kopalniane stwarzają bardzo duże zagrożenie dla środowiska przyrodniczego, o czym świadczą liczne katastrofy ekologiczne, do których doszło w wielu krajach (Nordstrom i in., 2000; Simón i in., 2001). Wody te charakteryzują się niskim $\mathrm{pH}(<4)$, przeważnie żółta, pomarańczową lub czerwoną barwą w różnych odcieniach, dużą zawartością (od kilkuset miligramów do kilkudziesięciu, a nawet kilkuset gramów na litr) siarczanów(VI)

\footnotetext{
${ }^{1}$ Wydział Matematyczno-Przyrodniczy, Uniwersytet Jana Kochanowskiego w Kielcach, ul. Świętokrzyska 15G, 25-406 Kielce; zmig@ujk.edu.pl
} 
Tab. 1. Zawartość REY w kwaśnych wodach kopalnianych wybranych obszarów [ $\mu \mathrm{g} / 1]$ Table 1. Concentrations of REY in AMD waters from selected areas $[\mu \mathrm{g} / \mathrm{L}]$

\begin{tabular}{|c|c|c|c|c|c|c|c|}
\hline REE $+Y$ & $\begin{array}{c}\text { Rio Tinto }{ }^{1} \\
\text { (Hiszpania / } \\
\text { Spain) }\end{array}$ & $\begin{array}{c}\text { Rio Agrio }^{2} \\
\text { (Argentyna / } \\
\text { Argentina) }\end{array}$ & $\begin{array}{c}\text { Metalliferous Hills }^{3} \\
\text { (Wlochy / Italy) }\end{array}$ & $\begin{array}{c}\text { Podwiśniówka }^{4} \\
\text { (zbiornik wodny / }^{\text {acid pit lake) }}\end{array}$ & $\begin{array}{c}\text { Wiśniówka }{ }^{4} \\
\text { (kaluże k. haldy / } \\
\text { pools near tailings } \\
\text { pile; } \mathrm{N}=14 \text { ) }\end{array}$ & $\begin{array}{c}\text { Wiśniówka }^{4} \\
\text { (superstężona } \\
\text { kaluża / } \\
\text { supersaturated } \\
\text { pool) }\end{array}$ & $\begin{array}{c}\text { Serwis }^{5} \\
\text { (kałuże / } \\
\text { pools) }\end{array}$ \\
\hline Y & n.o. & n.o. & n.o. & 207 & 5229 & 7944 & 450 \\
\hline $\mathrm{La}$ & 1780 & 410 & 185 & 62,6 & 1907 & 2418 & 31,2 \\
\hline $\mathrm{Ce}$ & 4480 & 560 & 390 & 184 & 5272 & 6883 & 216 \\
\hline $\operatorname{Pr}$ & 590 & 55 & 45,8 & 27 & 731 & 1017 & 44,8 \\
\hline $\mathrm{Nd}$ & 2580 & 240 & 172 & 138 & 3413 & 4797 & 286 \\
\hline $\mathrm{Sm}$ & 614 & 52 & 34,8 & 59,3 & 1226 & 1895 & 96,2 \\
\hline $\mathrm{Eu}$ & 65,4 & 16 & 8,65 & 15,4 & 335 & 498 & 20,7 \\
\hline $\mathrm{Gd}$ & 554 & 64 & 40,2 & 80,2 & 1752 & 2446 & 129 \\
\hline $\mathrm{Tb}$ & 54,7 & 11 & 5 & 11 & 267 & 390 & 15,6 \\
\hline Dy & 253 & 71 & 23,7 & 54 & 1416 & 2074 & 106 \\
\hline Ho & 37,2 & 16 & 4,18 & 8,67 & 253 & 391 & 17,2 \\
\hline $\mathrm{Er}$ & 85,9 & 52 & 10,5 & 21,8 & 638 & 936 & 51,9 \\
\hline $\mathrm{Tm}$ & 10,2 & 8,4 & 1,21 & 2,42 & 85,6 & 139 & 6,1 \\
\hline $\mathrm{Yb}$ & 61,7 & 61 & 7,07 & 17,8 & 540 & 835 & 39 \\
\hline $\mathrm{Lu}$ & 7,63 & 10 & 0,94 & 2,1 & 80,9 & 121 & 5,3 \\
\hline$\underset{(\mathrm{La}-\mathrm{Lu})}{\sum_{\mathrm{R}}}$ & 11174 & 1626 & 929 & 684 & 17916 & 24840 & 1065 \\
\hline
\end{tabular}

Objaśnienia / Explanations: ${ }^{1}$ Lecomte i in., 2017; ${ }^{2}$ Gammons i in., 2005b; ${ }^{3}$ Protano, Riccobono, 2002; ${ }^{4}$ Migaszewski i in., $2019 ;{ }^{5}$ Migaszewski $\mathrm{i}$ in., 2015; n.o. - nie oznaczono / not determined

żelaza, arsenu i różnych metali, w zależności od budowy geologicznej macierzystego obszaru (Nordstrom i in., 2000; Nordstrom, 2011; Migaszewski i in., 2019). Koryta strumieni, rzek i dna zbiorników wodnych są wyścielone tlenkami, wodorotlenkami i oksyhydroksysiarczanami żelaza lub też glinu o barwie żółtej, pomarańczowej, czerwonej i białej (zdjęcie na okładce, ryc. 1, 2A i ryc. 4-5 na str. 126).

Kwaśne wody kopalniane powstają w wyniku utlenienia pirytu, markasytu $\left(\mathrm{FeS}_{2}\right)$ i minerałów siarczkowych zawierających żelazo, np. arsenopirytu (FeAsS) czy chalkopirytu $\left(\mathrm{CuFeS}_{2}\right)$, w złożach rud polimetalicznych lub w zmineralizowanych formacjach skalnych. Proces ten przebiega dwutorowo. Początkowo, przy pH ok. 6, z udziałem rozpuszczonego w wodzie tlenu, a następnie, w miarę obniżania się $\mathrm{pH}$ poniżej 4, odpowiednio z udziałem jonów $\mathrm{Fe}^{3+}$, zgodnie z uproszczonymi reakcjami [1] i [2] (m.in. Garrels, Thompson, 1960; Singer, Stumm, 1970):

$$
\begin{aligned}
& \mathrm{FeS}_{2}+\frac{7}{2} \mathrm{O}_{2}+\mathrm{H}_{2} \mathrm{O} \rightarrow \mathrm{Fe}^{2+}+2 \mathrm{SO}_{4}^{2-}+2 \mathrm{H}^{+} \\
& \mathrm{FeS}_{2}+14 \mathrm{Fe}^{3+}+8 \mathrm{H}_{2} \mathrm{O} \rightarrow 15 \mathrm{Fe}^{2+}+2 \mathrm{SO}_{4}^{2-}+16 \mathrm{H}^{+} \\
& \mathrm{Fe}^{2+}+\frac{1}{4} \mathrm{O}_{2}+\mathrm{H}^{+} \rightarrow \mathrm{Fe}^{3+}+\frac{1}{2} \mathrm{H}_{2} \mathrm{O} \\
& \mathrm{Fe}^{3+}+3 \mathrm{H}_{2} \mathrm{O} \rightarrow \mathrm{Fe}(\mathrm{OH})_{3} \downarrow+3 \mathrm{H}^{+}
\end{aligned}
$$

$\mathrm{Z}$ kolei $\mathrm{Fe}^{2+}$ podlega utlenieniu do $\mathrm{Fe}^{3+}$ [reakcja 3], które albo utlenia piryt [reakcja 2], albo podlega hydrolizie, zgodnie z reakcją [4]. Procesy te są katalizowane przez bakterie, m.in. z gatunków Acidithiobacillus ferrooxidans, A. thiooxidans lub Leptospirillum ferrooxidans, które kilkakrotnie zwiększają tempo reakcji. Izomorficzne domieszki pierwiastków w pirycie (m.in. As, $\mathrm{Cu}, \mathrm{Ni}$ ) są uwalniane do środowiska wodnego, a powstałe produkty wietrzenia wchodzą w reakcję $\mathrm{z}$ różnymi minerałami siarczkowymi i towarzyszącymi, np. z galeną (PbS), prowadząc do powstania dodatkowych jonów wodorowych:

$$
\begin{aligned}
& 2 \mathrm{PbS}+4 \mathrm{Fe}^{3+}+6 \mathrm{SO}_{4}^{2-}+3 \mathrm{O}_{2}+2 \mathrm{H}_{2} \mathrm{O} \rightarrow \\
& 2 \mathrm{PbSO}_{4}+4 \mathrm{Fe}^{2+}+6 \mathrm{SO}_{4}^{2-}+4 \mathrm{H}^{+}
\end{aligned}
$$

Należy podkreślić, że pH kwaśnych wód kopalnianych kontrolują nie tylko opisane reakcje chemiczne, lecz również skład mineralny towarzyszących im koloidów i osadów. Podstawowym minerałem wtórnym jest schwertmannit $\mathrm{Fe}_{8} \mathrm{O}_{8}(\mathrm{OH})_{5,5}\left(\mathrm{SO}_{4}\right)_{1,25}$, który w warunkach $\mathrm{pH}$ poniżej 2,5-2,8 ulega przekształceniu w jarosyt $\mathrm{KFe}^{3+}{ }_{3}\left[(\mathrm{OH})_{6}\left(\mathrm{SO}_{4}\right)_{2}\right]$ lub jarosyt hydroniowy $\left(\mathrm{H}_{3} \mathrm{O}\right) \mathrm{Fe}^{3+}{ }_{3}\left[(\mathrm{OH})_{6}\left(\mathrm{SO}_{4}\right)_{2}\right]$. Wraz ze wzrostem $\mathrm{pH}$ schwertmannit ulega transformacji w nanokoloidalny ferrihydryt $\mathrm{Fe}^{3+}{ }_{5} \mathrm{O}_{6}[\mathrm{OH}]_{3} \cdot 3 \mathrm{H}_{2} \mathrm{O}$ (w warunkach pH od 2,5 do 4,5), a ten kolejno - w amorficzno-mikrokrystaliczną mieszaninę goethytu $\alpha-\mathrm{Fe}^{3+} \mathrm{O}(\mathrm{OH})$, lepidokrokitu $\gamma-\mathrm{Fe}^{3+} \mathrm{O}(\mathrm{OH})$, akaganéitu $\beta-\mathrm{Fe}^{3+}(\mathrm{O}, \mathrm{OH}, \mathrm{Cl})$ i na końcu (pH 3-7) w krystaliczny hematyt $\alpha-\mathrm{Fe}_{2} \mathrm{O}_{3}$ (m.in. Bigham, 1992; Schwertmann i in., 1995). Produkty wietrzenia pirytu wchodzą też $\mathrm{w}$ reakcję $\mathrm{z}$ minerałami zawierającymi pierwiastki ziem rzadkich, np. $\mathrm{z}$ fosforanami, w tym ksenotymem-(Y) $\mathrm{Y}\left[\mathrm{PO}_{4}\right]$, monacytem $\mathrm{Ce}\left[\mathrm{PO}_{4}\right]$ oraz glinofosforanami $\mathrm{z}$ grupy crandallitu, np. goyazytem $\mathrm{SrAl}_{3} \mathrm{H}\left[(\mathrm{OH})_{6}\left(\mathrm{PO}_{4}\right)_{2}\right]$, gorceixytem $\mathrm{BaAl}_{3} \mathrm{H}\left[(\mathrm{OH})_{6}\left(\mathrm{PO}_{4}\right)_{2}\right]$ i crandallitem $\mathrm{CaAl}_{3} \mathrm{H}\left[(\mathrm{OH})_{6}\left(\mathrm{PO}_{4}\right)_{2}\right]$ (Migaszewski i in., 2007, 2016, 2018b, 2019; Migaszewski, Gałuszka, 2010). 


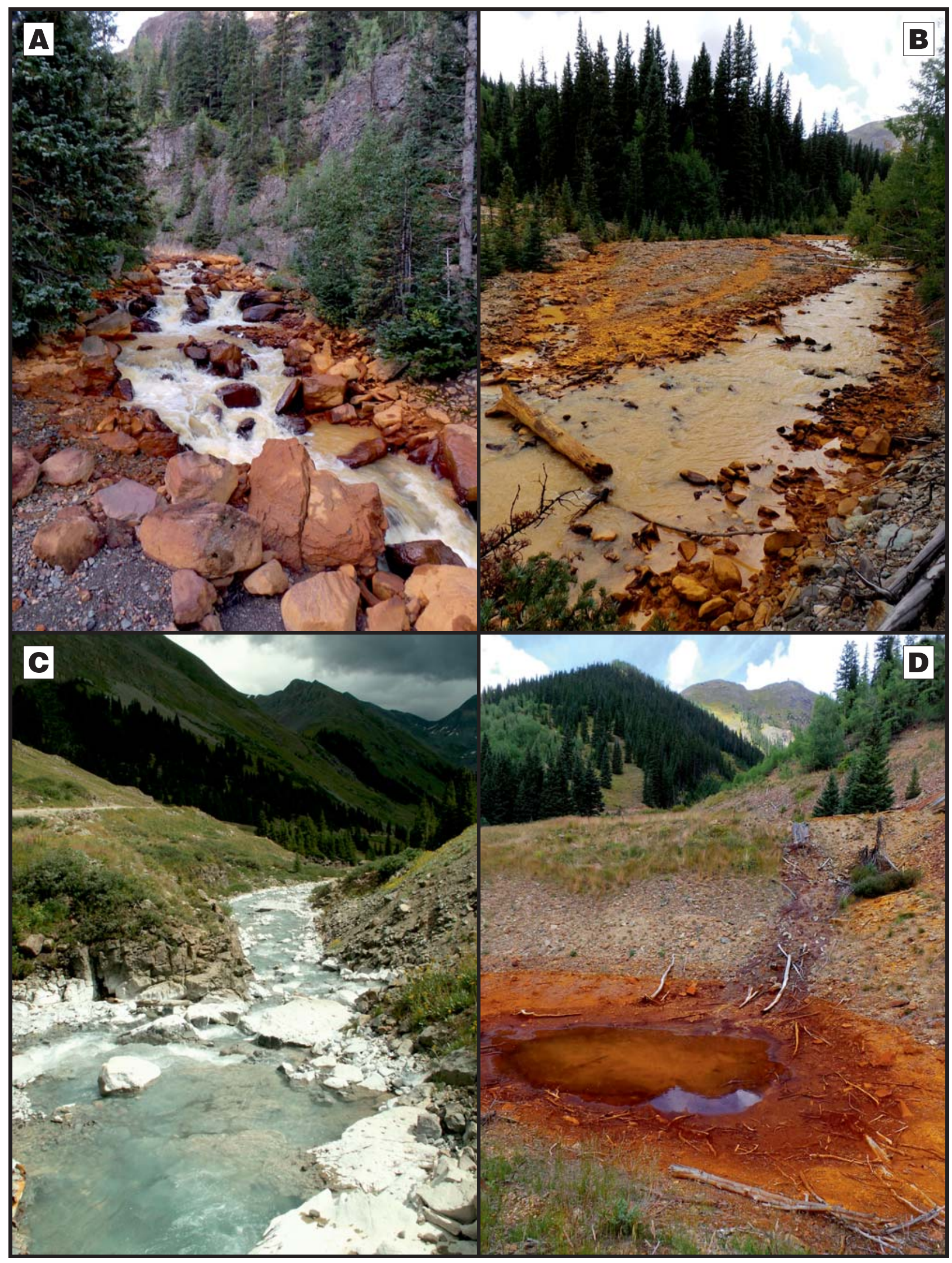

Ryc. 1. Przykłady różnych środowisk kwaśnych wód kopalnianych z rejonu Silverton-Ouray (SW Kolorado, USA): A, B - Red Mountain Creek zasilany przez strumienie kwaśnych wód kopalnianych, w połowie drogi między przełęczą Red Mountain Pass a miasteczkiem Ouray; C - koryto jednego ze strumieni wyścielone tlenkami i wodorotlenkami glinu w pobliżu Animas Forks w rejonie Silverton; D - źródło kwaśnych wód kopalnianych w dolinie Cement Creek w rejonie Silverton

Fig. 1. Examples of different AMD environments from the Silverton-Ouray area (SW Colorado, USA): A, B - Red Mountain Creek recharged by AMD creeks halfway between the Red Mountain Pass and a small town of Ouray; $\mathbf{C}$ - creek bed veneered with aluminum oxyhydroxides at the Animas Forks near Silverton; D - AMD spring in the Cement Creek valley near Silverton 


\section{WLAŚCIWOŚCI FIZYKOCHEMICZNE I WYSTĘPOWANIE PIERWIASTKÓW ZIEM RZADKICH}

Pierwiastki ziem rzadkich są litofilne. W strukturze krzemianów, rzadziej węglanów, tlenków, wodorotlenków i fosforanów podstawiają kationy o zbliżonym promieniu jonowym i ładunku. Według IUPAC (International Union of Pure and Applied Chemistry) należą one do grupy 3 układu okresowego, w której obejmują lantanowce o liczbie atomowej od $57(\mathrm{La})$ do $71(\mathrm{Lu})$ i dodatkowo dwa pierwiastki: itr ( $Y ; Z=39)$ i skand ( $S c ; Z=21)$. Należy jednak podkreślić, że większość badaczy reprezentujących nauki o Ziemi wyłącza skand z tej listy, z uwagi na jego mały promień jonowy - pod pojęciem pierwiastki ziem rzadkich rozumie tylko lantanowce ( $\mathrm{Ln}) \mathrm{i}$ tak, jak autorzy tego artykułu, oba terminy stosuje wymiennie. Z kolei itr, o promieniu jonowym zbliżonym do holmu (Ho), jest traktowany osobno, choć w literaturze geochemicznej, a szerzej geologicznej, jest on często omawiany wraz z lantanowcami, czyli REE sensu stricto (REY). W grupie lantanowców promet $(\mathrm{Pm})$ jest jedynym pierwiastkiem, który nie tworzy trwałych izotopów i składa się z 5 radionuklidów o krótkim okresie połowicznego rozpadu. Ilość najbardziej rozpowszechnionego izotopu ${ }^{147} \mathrm{Pm}$ w litosferze nie przekracza $600 \mathrm{~g}$ (Belli i in., 2007) i z tego też względu nie jest on oznaczany i zwykle bywa pomijany w charakterystyce geochemicznej lantanowców.

Z wyjątkiem ceru $\left(\mathrm{Ce}^{3+}, \mathrm{Ce}^{4+}\right)$ i europu $\left(\mathrm{Eu}^{2+}, \mathrm{Eu}^{3+}\right)$ pozostałe lantanowce występuja $\mathrm{w}$ przyrodzie na +3 stopniu utlenienia, a ich promienie jonowe maleją wraz ze wzrostem liczby atomowej i wynoszą od $103 \mathrm{pm}$ - promień jonowy lantanu $\left(\mathrm{La}^{3+}\right)$ do $86 \mathrm{pm}$ - promień lutetu $\left(\mathrm{Lu}^{3+}\right)$. Zjawisko to jest zwane kontrakcją lantanowców. Lantanowce spełniają regułę Oddo-Harkinsa, tzn. pierwiastki o parzystych liczbach atomowych charakteryzują się większym wzbogaceniem (mają wyższe klarki) niż ich odpowiedniki o nieparzystych liczbach atomowych, jak również większą liczbą izotopów, np. iterb $(\mathrm{Yb} ; \mathrm{Z}=70)$ ma 7 izotopów, natomiast tul $(\mathrm{Tm} ; Z=69)$ ma tylko 1 izotop (Migaszewski, Gałuszka, 2015 i literatura tam cytowana).

Pierwiastki ziem rzadkich, wbrew swojej nazwie, dość powszechnie występują w górnej części skorupy ziemskiej - stanowiąc ok. 0,015\% jej objętości. Jest ich w niej więcej niż Ag i Hg, a ilość samego ceru przewyższa nawet klarki $\mathrm{Cu}$ i Pb (Taylor, McLennan, 1985). Jednak złoża tych pierwiastków należą do rzadkości i są przeważnie związane z występowaniem karbonatytów, skał peralkalicznych i różnych utworów hydrotermalnych (Kynicky i in., 2012). Największe zasoby eksploatacyjne rud pierwiastków ziem rzadkich na świecie znajdują się w Chinach (powyżej 90\%), w tym w słynnym złożu Fe-REE-Nb w Bayan Obo w Wewnętrznej Mongolii (USGS, 2012). Należy też podkreślić, że w ostatnich latach na światową potęge pod względem zasobów rud REE zaczyna wyrastać Korea Północna (Maksymowicz, 2019).

Najbardziej rozpowszechnionymi minerałami REE o znaczeniu ekonomicznym są: bastnäsyt $-\mathrm{REECO}_{3}(\mathrm{~F}, \mathrm{OH})$, parasyt $-\mathrm{CaREE}_{2}\left(\mathrm{CO}_{3}\right)_{3}(\mathrm{~F}, \mathrm{OH})_{2}$, synchisyt $-\mathrm{CaREE}\left(\mathrm{CO}_{3}\right)_{2}$. $(\mathrm{F}, \mathrm{OH})$, Ba-REE fluoroweglany - $\mathrm{Ba}_{\mathrm{x}} \mathrm{REE}_{\mathrm{y}}\left(\mathrm{CO}_{3}\right)_{\mathrm{x}+\mathrm{y}} \mathrm{F}_{\mathrm{y}}$, monacyt - REE $\left[\mathrm{PO}_{4}\right]$ oraz ksenotym - Y $\left[\mathrm{PO}_{4}\right]$. Złoża bastnäsytu w Chinach i USA zawierają największe zasoby rud REE na świecie. Na drugim miejscu są złoża monacytu, m.in. w Australii, Brazylii, Chinach, Indiach i Południowej Afryce (USGS, 2012).
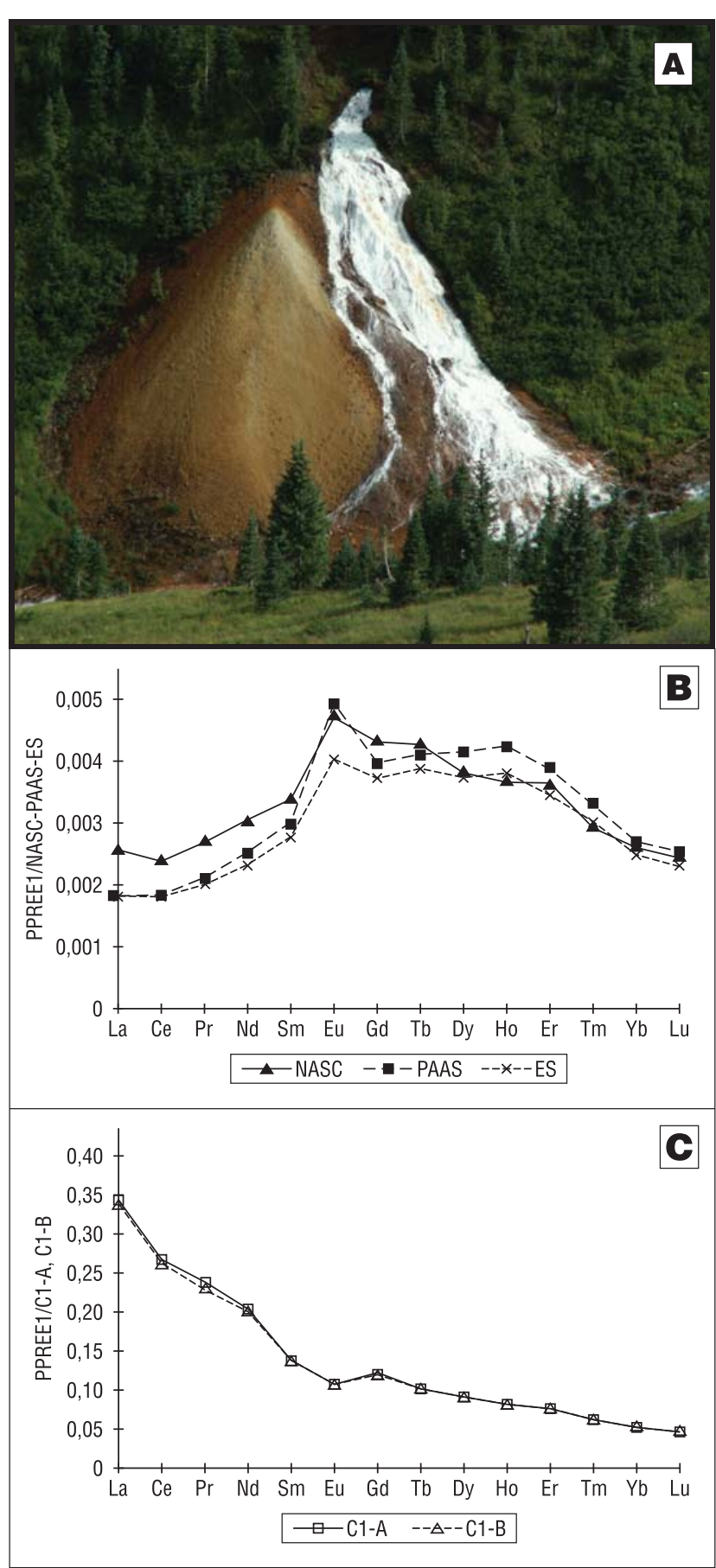

Ryc. 2A - Strumień w pobliżu przełęczy Ophir Pass (rejon Silverton), który wypływa z nieczynnej sztolni. Dno strumienia jest wyścielone tlenkami i wodorotlenkami glinu. $Z$ wody tego strumienia pochodzi materiał odniesienia PPREE1 (vide tab. 2), użyty do obliczenia znormalizowanych wartości stężeń REE w B i C; B - Krzywe stężeń REE w PPREE1 znormalizowane do NASC, PAAS i ES z wyraźną dodatnią anomalią europu; $\mathbf{C}$ - Krzywe stężeń REE w PPREE1 znormalizowane do chondrytu węglistego C1-A i C1-B (odpowiednio Anders, Grevesse, 1989; McDonough, Sun, 1995; vide tab. 2)

Fig. $2 \mathrm{~A}-\mathrm{A}$ view of the stream flowing out of the abandoned adit and veneered with aluminum oxyhydroxides, near the Ophir Pass (Silverton area). This water is a source of the standard reference material (PPREE1) used for computing normalized REE-concentrations in B and C (see Table 2); B - NASC-, PAAS- and ES-normalized REE concentration patterns of PPREE1 with a distinct positive europium anomaly; $\mathbf{C}-\mathrm{C} 1-\mathrm{A}-$ and $\mathrm{C} 1-\mathrm{B}-$ normalized REE concentration patterns of PPREE1 (Anders, Grevesse, 1989; McDonough, Sun, 1995, respectively; see Table 2) 


\section{KLASYFIKACJE I ANOMALIE LANTANOWCÓW}

Właściwości fizykochemiczne są podstawą podziału lantanowców na dwie podgrupy: 1) lekkie REE (LREE light rare earth elements) z preferowanym przez autorów zakresem od La do Eu (niekiedy od La do Gd) i 2) ciężkie REE (HREE - heavy rare earth elements) - od Gd do Lu. Większość badaczy zajmujących się problematyką lantanowców wyróżnia także trzecią podgrupę - 3) pośrednich pierwiastków ziem rzadkich (MREE - medium rare earth elements), obejmującą częściowo ich lżejsze i cięższe odpowiedniki - na ogół od Sm do Dy (Migaszewski i in., 2016, 2019). Trzeba jednak podkreślić, że niektórzy autorzy (m.in. Grawunder i in., 2014; Soyol-Erdene i in., 2018) proponują następujący podział lantanowców: 1) LREE (La, Ce, Pr, Nd, Pm), 2) MREE (Sm, Eu, Gd, Tb, Dy) i 3) HREE (Ho, Er, Tm, Yb, Lu). Brak jednolitej klasyfikacji lantanowców powoduje często duże zamieszanie w przypadku porównywania poszczególnych podgrup tych pierwiastków, tym bardziej że niektórzy autorzy zaliczają itr do podgrupy HREE, zawyżając $w$ ten sposób zawartość lantanowców w różnych elementach środowiska przyrodniczego.

Aby wyeliminować zygzakowaty profil lantanowców, wynikający ze wspomnianej wcześniej reguły Oddo-Harkinsa, celem identyfikacji dodatnich i ujemnych anomalii pojedynczych pierwiastków, pomierzoną zawartość REE normalizuje się do różnych zbiorów odniesienia. W użyciu są 3 podstawowe skale (czy też zbiory) odniesienia:

1) meteorytowa - chondrytu węglistego $\mathrm{C} 1$ (ClChondritic Meteorite; McDonough, Sun, 1995);

2) północnoamerykańskiego łupku złożonego (NASC - North American Shale Composite; Haskin i in., 1968; Gromet i in., 1984);
3) postarchaicznego łupku australijskiego (PAAS Post-Archean Australian Shale; McLennan, 1989; Pourmand i in., 2012).

Bau i współautorzy (2018) zaproponowali dla materiałów środowiskowych z Europy tzw. łupek europejski. Wartości odniesienia tych czterech zbiorów przedstawiono w tabeli 2 . Chondryty reprezentują materiał protoplanetarny i ich wartości odniesienia są używane w badaniach procesów endogenicznych i w modelowaniach petrogenetycznych, natomiast łupki są wykorzystywane $\mathrm{w}$ badaniach procesów hipergenicznych, zachodzących w różnych elementach środowiska przyrodniczego, np. w wodach, osadach, glebach i roślinach (Dołegowska, Migaszewski, 2013). Ponieważ wymienione zbiory (skale) odniesienia charakteryzują się różną zawartością poszczególnych lantanowców, dając różne profile dla tych samych, mierzonych ilości lantanowców, dlatego też w przypadku badania 2-3 elementów środowiska (np. skał, wód i roślin) należy stosować tylko jeden określony zbiór odniesienia. Niewłaściwe użycie zbioru odniesienia może prowadzić do błędnej interpretacji, co najlepiej można zaobserwować porównując krzywe na rycinie $2 \mathrm{BC}$, znormalizowane względem materiału odniesienia PPREE1 (tab. 2). Profile REE tego materiału, znormalizowane do NASC, PAAS i ES, są do siebie zbliżone i wykazują wyraźną anomalię dodatnią europu przy jednoczesnym wzbogaceniu w cięższe lantanowce. Natomiast profil REE znormalizowany do chondrytu węglistego $\mathrm{C} 1$ ma zupełnie inny przebieg, z wyraźną przewagą lekkich lantanowców.

Innym ważnym zagadnieniem jest obliczanie znormalizowanych współczynników wzbogacenia pojedynczych lantanowców, które nie zawsze korespondują z kształtem krzywej znormalizowanych stężeń tych pierwiastków.

Tab. 2. Zawartość REY w chondrycie, łupkach i kwaśnych wodach kopalnianych (materiały odniesienia PPREE1, SCREE1)

Table 2. REY concentrations in chondritic meteorite, shales and acid mine drainage waters (standard reference materials PPREE1, SCREE1)

\begin{tabular}{|c|c|c|c|c|c|c|c|c|c|c|}
\hline \multirow{2}{*}{$\mathbf{R E E}+\mathbf{Y}$} & $\begin{array}{c}\text { C1-A } \\
\text { Chondrite }^{1}\end{array}$ & $\begin{array}{c}\text { C1-B } \\
\text { Chondrite }^{2}\end{array}$ & NASC $^{3}$ & NASC $^{4}$ & NASC $^{5}$ & PAAS $^{6}$ & PAAS $^{7}$ & $\mathbf{E S}^{8}$ & PPREE1 $^{9}$ & SCREE1 $^{9}$ \\
\hline & \multicolumn{2}{|c|}{$[\mu \mathrm{g} / \mathbf{k g}]$} & \multicolumn{6}{|c|}{$[\mathrm{mg} / \mathrm{kg}]$} & \multicolumn{2}{|c|}{$[\mu \mathrm{g} / \mathrm{l}]$} \\
\hline Y & 1560 & 1570 & 27 & & 27 & 27 & 27,31 & 31,9 & & \\
\hline $\mathrm{La}$ & 234,7 & 237 & 32 & 31,1 & 31,1 & 38,2 & 44,56 & 44,3 & 80,4 & 9,85 \\
\hline $\mathrm{Ce}$ & 603,2 & 613 & 70 & 66,7 & 67,033 & 79,6 & 88,25 & 88,5 & 161 & 24,6 \\
\hline $\operatorname{Pr}$ & 89,1 & 92,8 & 7,9 & & 7,9 & 8,83 & 10,15 & 10,6 & 21,2 & 4,29 \\
\hline $\mathrm{Nd}$ & 452,4 & 457 & 31 & 27,4 & 30,4 & 33,8 & 37,32 & 39,5 & 92,3 & 22,1 \\
\hline $\mathrm{Sm}$ & 147,1 & 148 & 5,7 & 5,59 & 5,98 & 5,55 & 6,884 & 7,3 & 20,3 & 6,71 \\
\hline $\mathrm{Eu}$ & 56 & 56,3 & 1,24 & 1,18 & 1,253333 & 1,08 & 1,215 & 1,48 & 5,95 & 1,47 \\
\hline $\mathrm{Gd}$ & 196,6 & 199 & 5,21 & & 5,5 & 4,66 & 6,043 & 6,34 & 23,8 & 8,21 \\
\hline $\mathrm{Tb}$ & 36,3 & 36,1 & 0,85 & 0,85 & 0,85 & 0,774 & 0,8914 & 0,944 & 3,65 & 1,34 \\
\hline Dy & 242,7 & 246 & 5 & & 5,75 & 4,68 & 5,325 & 5,86 & 22 & 8,1 \\
\hline Ho & 55,6 & 54,6 & 1,04 & & 1,2 & 0,991 & 1,053 & 1,17 & 4,43 & 1,61 \\
\hline $\mathrm{Er}$ & 158,9 & 160 & 3,4 & & 3,275 & 2,85 & 3,075 & 3,43 & 11,9 & 4,35 \\
\hline $\mathrm{Tm}$ & 24,2 & 24,7 & 0,5 & & 0,5 & 0,405 & 0,451 & 0,492 & 1,48 & 0,582 \\
\hline $\mathrm{Yb}$ & 162,5 & 161 & 3,1 & 3,06 & 3,113333 & 2,82 & 3,012 & 3,26 & 8,2 & 3,39 \\
\hline $\mathrm{Lu}$ & 24,3 & 24,6 & 0,48 & 0,456 & 0,456 & 0,433 & 0,4386 & 0,485 & 1,12 & 0,452 \\
\hline
\end{tabular}

Objaśnienia / Explanations: ${ }^{1}$ Anders, Grevesse, $1989 ;{ }^{2}$ McDonough, Sun, $1995 ;{ }^{3}$ Haskin i in., 1968; ${ }^{4}$ Gromet i in., $1984 ;{ }^{5}$ NASC zmodyfikowane (stosowane przez autorów); ${ }^{6}$ McLennan $1989 ;{ }^{7}$ Pourmand i in., 2012; ${ }^{8}$ Bau i in., 2018; ${ }^{9}$ Verplanck i in., 2001 - PPREE1 - Paradise Portal (w pobliżu przełęczy Ophir / near Ophir Pass, San Juan Mountains, SW Kolorado), SCREE1 - Spring Creek (północna Kalifornia / northern California) 
Należy przy tym pamiętać, że w równaniu należy uwzględnić dwa najbliżej sąsiadujące pierwiastki, które nie wykazują anomalii, jeśli np. cer - w przeciwieństwie do sąsiadującego lantanu i prazeodymu - wykazuje anomalię dodatnią w określonym łupku (NASC, PAAS, ES - vide tab. 2), to wartość tej anomalii oblicza się zgodnie z równaniem (Bau, Dulski, 1996):

$$
\mathrm{Ce} / \mathrm{Ce}_{\text {tupek }}{ }^{*}=\mathrm{Ce}_{\text {tupek }} /\left(0,5 \mathrm{La}_{\text {tupek }}+0,5 \mathrm{Pr}_{\text {tupek }}\right)
$$

lub w postaci logarytmicznej:

$$
\mathrm{Ce} / \mathrm{Ce}_{\text {lupek }}{ }^{*}=\mathrm{Ce}_{\text {tupek }} /\left(\mathrm{La}_{\text {lupek }} \times \mathrm{Pm}_{\text {lupek }}\right)^{0,5}
$$

Ze względu na błąd pomiaru wartości liczbowe współczynników anomalii poniżej 0,8 wskazują na anomalię ujemną, natomiast powyżej 1,2 - na anomalię dodatnią (Grawunder i in., 2014, Migaszewski i in., 2016, 2019). Wartości z przedziału $0,8-1,2$ nie należy więc traktować jak anomalie, jak to często spotyka się w literaturze geologicznej, np. wartość 1,1 nie jest dodatnią anomalią. Podobnie, w przypadku udokumentowania przewagi jednej z podgrup lantanowców, oblicza się współczynniki znormalizowane do określonej skali, np. łupku: $\mathrm{La}_{\text {łupek }} / \mathrm{Yb}_{\text {łupek }}, \mathrm{La}_{\text {łupek }} / \mathrm{Sm}_{\text {lupek }}$ i $\mathrm{Sm}_{\text {tupek }} / \mathrm{Yb}_{\text {lupek }}$. Umożliwiają one określenie zubożenia $(<0,8)$ lub wzbogacenia $(>1,2)$ podgrup: LREE (La), MREE (Sm) i HREE (Yb).

Na rycinie 3 przedstawiono profil lantanowców z nowego zbiornika kwaśnych wód kopalnianych w Podwiśniówce (Migaszewski i in., 2019) i odpowiednie współczynniki normalizacyjne. Na wykresie widać, że anomalia dodatnia stężeń REE znormalizowanych do NASC obejmuje pierwiastki od Sm do Er, co znajduje potwierdzenie w wartościach współczynników anomalii w zakresie od 1,33 (Er) do 2,87 (Gd), w stosunku do pierwiastków niewykazujących anomalii (Nd i Tm). O wyraźnym wzbogaceniu w MREE świadczą też współczynniki $\mathrm{La}_{\mathrm{NASC}} / \mathrm{Sm}_{\mathrm{NASC}}$ $(0,21)$ i $\mathrm{Sm}_{\mathrm{NASC}} / \mathrm{Yb}_{\mathrm{NASC}}(1,71)$. Z kolei Yb nie wykazuje anomalii dodatniej, ponieważ $\mathrm{w}$ stosunku do Tm i Lu współczynnik $\mathrm{Yb} / \mathrm{Yb}_{\mathrm{NASC}}{ }^{*}$ wynosi $1,09(<1,2)$.

\section{METODYKA BADAŃ PIERWIASTKÓW ZIEM RZADKICH}

Pobieranie i przygotowanie próbek środowiskowych należy do kluczowych etapów całej procedury analitycznej. Pobrana próbka musi być reprezentatywna, homogeniczna, wolna od zanieczyszczeń i rzeczywista - czyli niezmieniona $\mathrm{w}$ trakcie pobierania, przechowywania, transportu i przygotowania (Ramsey i in., 1992; Migaszewski, Gałuszka, 2016). Próbek kwaśnych wód kopalnianych nie należy utrwalać z uwagi na możliwość uruchomienia dodatkowych reakcji prowadzących do zmiany ich składu chemicznego. W ramach kontroli jakości jednym z najważniejszych elementów analizy jest dobór właściwego materiału odniesienia o odpowiedniej matrycy, np. PPREE1 lub SCREE1 (tab. 2).

Pierwsze oznaczenia pierwiastków ziem rzadkich wykonano za pomocą instrumentalnej neutronowej analizy aktywacyjnej (INAA; m.in. Goldberg i in., 1963; Salvini i in., 2006). Jednak pewne ograniczenia sprawiały (badana próbka ulegała napromieniowaniu), że technika ta nie była często stosowana. Powszechne oznaczanie pier- wiastków ziem rzadkich stało się możliwe dzięki rozwojowi standardowych technik spektrometrii mas, szczególnie z użyciem kwadrupolowego spektrometru mas z jonizacja w plazmie indukcyjnie sprzężonej (Q-ICP-MS) lub wielokolektorowego spektrometru mas $\mathrm{z}$ jonizacją $\mathrm{W}$ plazmie indukcyjnie sprzężonej (MC-ICP-MS; m.in. Baker i in., 2002; Merten, Büchel, 2004; Zawisza i in., 2011).

Pierwiastki ziem rzadkich można oznaczać w próbkach wody, wykorzystując różne techniki instrumentalne, w tym spektroskopię UV-Vis, atomową spektroskopię absorpcyjną (ASA), optyczną spektrometrię emisyjną z jonizacją w plazmie indukcyjnie sprzężonej (ICP-OES), spektrometrię mas $\mathrm{z}$ jonizacją $\mathrm{W}$ plazmie indukcyjnie sprzężonej (ICP-MS), instrumentalną neutronową analizę aktywacyjną (INAA), potencjometrię, woltamperometrię absorpcyjna, spektroskopię fluorescencji rentgenowskiej całkowitego odbicia (TR-XRF) czy też techniki łączone, np. elektroforezę kapilarną ze spektroskopią UV-Vis (Fisher, Kara, 2016). Wśród wymienionych technik najpopularniejszą i zalecaną do badania próbek wód w celu oznaczenia pierwiastków ziem rzadkich jest spektrometria mas z jonizacją w plazmie indukcyjnie sprzężonej (ICP-MS). Wynika to $\mathrm{z}$ dużej czułości, umożliwiającej oznaczenie śladowych ilości REE (niskie granice oznaczalności), dużej selektywności oraz możliwości jednoczesnego oznaczenia wszystkich REE w badanej próbce.

Mimo wielu zalet techniki ICP-MS w analizie próbek wód na zawartość REE, trudność może sprawić oznaczenie gadolinu, lutetu czy europu, ze względu na interferencje spektralne od jonów poliatomowych tworzonych w plazmie - np. ${ }^{140} \mathrm{Ce}^{16} \mathrm{O}^{+}$zawyża stężenie ${ }^{156} \mathrm{Gd}^{+},{ }^{159} \mathrm{~Tb}^{16} \mathrm{O}^{+}$ wpływa na pomiar ${ }^{175} \mathrm{Lu}^{+}$, a obecność $\mathrm{w}$ próbce baru zakłóca oznaczanie izotopów europu $-{ }^{151} \mathrm{Eu}^{+} \mathrm{i}{ }^{153} \mathrm{Eu}^{+}$ (interferencje pochodzące od ${ }^{135} \mathrm{Ba}^{16} \mathrm{O}^{+} \mathrm{i}^{137} \mathrm{Ba}^{16} \mathrm{O}^{+}$). Niezależnie od stosowanej metody analitycznej i rodzaju badanych próbek wód, dużą niedogodnością jest niedostateczna dostępność certyfikowanych materiałów odniesienia, które wykorzystuje się do sprawdzenia dokładności pomiarów analitycznych. W większości badań stosuje się materiały odniesienia, w których zawartość REE została określona przez pojedyncze laboratoria, np. NASS-5 - North Atlantic Surface Seawater, CASS-4 - Coastal Atlantic Surface Seawater oraz SLEW-3 - The Estuarine Water (Lawrence, Kamber, 2007). Analizy próbek kwaśnych wód kopalnianych powinny być wykonywane $\mathrm{z}$ użyciem dwóch materiałów odniesienia o najlepiej dopasowanej do nich matrycy próbki: PPREE1 i SCREE1, przygotowanych przez Służbę Geologiczną Stanów Zjednoczonych z rzeczywistych wód kopalnianych (Verplanck i in., 2001).

W przypadku badania próbek wód naturalnych na zawartość pierwiastków ziem rzadkich częstym problemem jest konieczność wzbogacenia w tych próbkach oznaczanych pierwiastków ze względu na ich bardzo małe stężenia. Problem ten nie dotyczy jednak kwaśnych wód kopalnianych, których próbki mogą być bezpośrednio analizowane techniką ICP-MS (Merten, Büchel, 2004). Szczegóły procedur analitycznych wykorzystywanych do izolacji, wzbogacania i oznaczania REE w kwaśnych wodach kopalnianych nie mieszczą się w tematyce tego artykułu, zainteresowany czytelnik może je znaleźć w publikacji Fisher i Kary (2016).

Metody petrograficzne i mineralogiczne stanowią integralną część analiz chemicznych w środowiskach występo- 


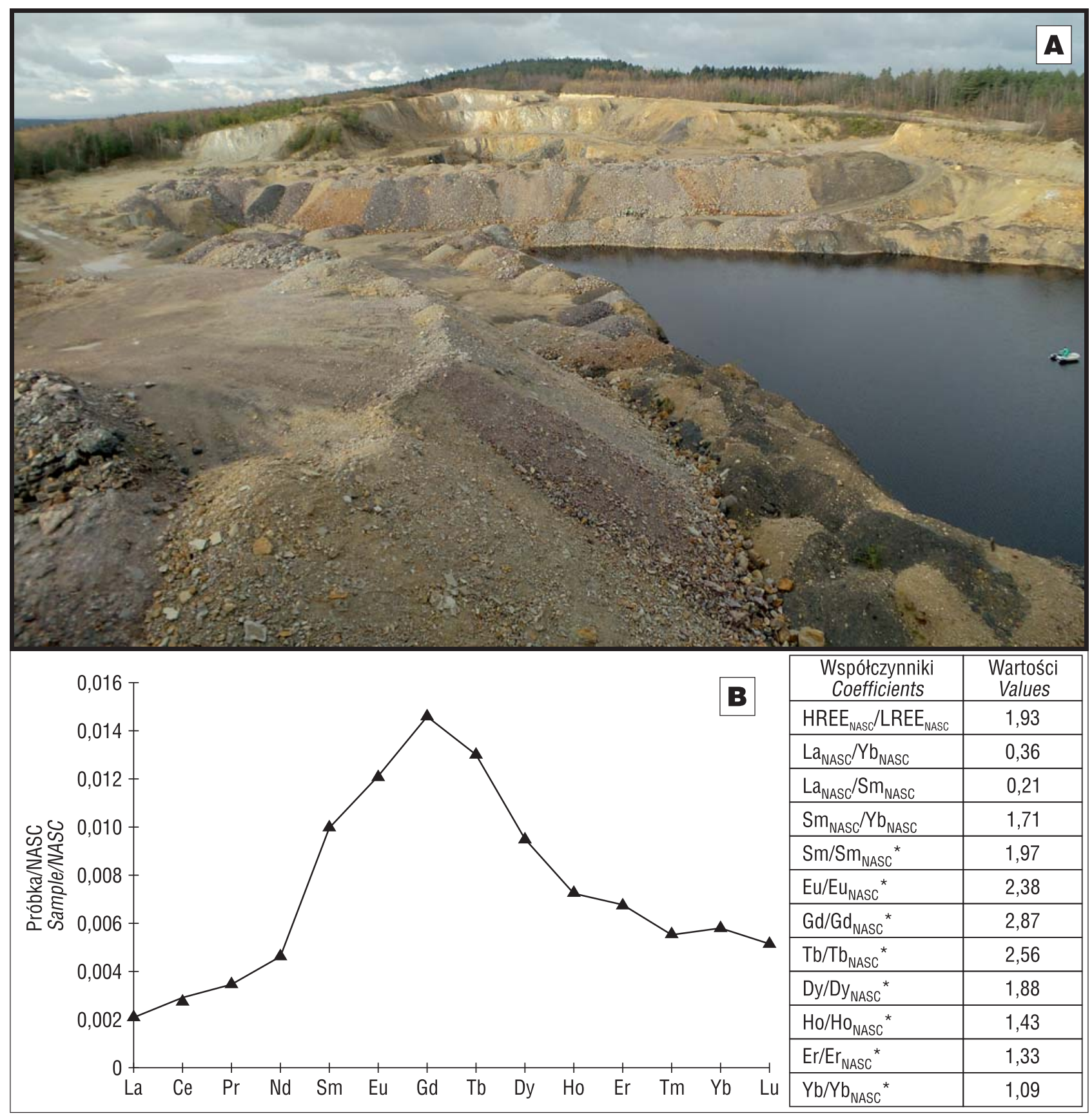

Ryc. 3A - Kamieniołom Podwiśniówka wraz z południową częścią kwaśnego zbiornika (zdjęcie wykonano 15.11.2018 r.); B - Znormalizowany do NASC profil średnich stężeń REE (N = 11) w kwaśnych wodach zbiornika Podwiśniówka (Migaszewski i in., 2019) wraz z obliczonymi współczynnikami anomalii stężeń lantanowców znormalizowanych do NASC

Fig. 3A - The Podwiśniowka quarry with the southern part of the AMD pit lake (the photograph was taken on 15.11.2018); B NASC-normalized mean REE concentration pattern $(\mathrm{N}=11)$ of the Podwiśniówka acid pit lake (Migaszewski et al., 2019) with computed anomaly coefficients of NASC-normalized concentrations of individual lanthanides

wania kwaśnych wód kopalnianych - obejmują one skały macierzyste, minerały siarczkowe oraz koloidy i osady (Plumlee, 1999). Ich celem jest wyjaśnienie pochodzenia pierwiastków obecnych w kwaśnych wodach kopalnianych oraz prześledzenie ich obiegu w kontekście powstawania, transformacji i depozycji minerałów wtórnych. W ramach tych badań stosuje się różne metody mikroskopowe, najczęściej z użyciem mikroskopów optycznych (stereoskopowych, petrograficznych) i skaningowych mikroskopów elektronowych ze spektrometrią dyspersji energii (SEM-EDS), rzadziej transmisyjnych mikroskopów elektronowych (TEM). Dodatkowo do mikroanalizy różnych faz mineralnych wykorzystuje się mikrosondy elektronowe (EMP) i jonowe (IMP), ablację laserową sprzężoną ze spektrometrem mas $\mathrm{z}$ jonizacją $\mathrm{w}$ plazmie indukcyjnie sprzężonej (LA-ICP-MS; m.in. Orihashi, Hirata, 2003; Migaszewski i in., 2018a, b, 2019) lub wtórną jonową spektrometrię mas (SIMS; Wiedenbeck i in., 1995).

Dużą rolę w badaniach osadów i koloidów w środowiskach kwaśnych wód kopalnianych odgrywają też metody rentgenostrukturalne (XRD) i transmisyjnej spektroskopii Mössbauerowskiej (TMS). Obie metody uzupełniają się w przypadku współwystępowania mikrokrystalicznych i nanokoloidalnych faz minerałów ilastych oraz tlenków i wodorotlenków żelaza (Murad, 2010; Houben, Kaufhold, 2011). 


\section{INTERAKCJE GEOCHEMICZNE LANTANOWCÓW W ŚRODOWISKACH KWAŚNYCH WÓD KOPALNIANYCH}

Do 1979 r. panowało przekonanie, że pierwiastki ziem rzadkich nie są mobilne i nie podlegają frakcjonowaniu $\mathrm{w}$ trakcie wietrzenia w warunkach temperatur i ciśnień notowanych na powierzchni Ziemi (Nesbitt, 1979). Należy jednak podkreślić, że mimo kompleksowych badań kwaśnych wód kopalnianych, prowadzonych w wielu krajach, nie zostały w pełni wyjaśnione mechanizmy i uwarunkowania wpływające na różne interakcje geochemiczne, zachodzące między wodami i minerałami pierwotnymi lub wtórnymi, w aspekcie mobilności lantanowców. Wynika to z nakładania się różnych czynników związanych z odmienną rozpuszczalnością minerałów pierwotnych zawierających REE, jak również z początkową adsorpcją (lub desorpcją), a następnie, w miarę wzrostu pH, readsorpcją i współwytrącaniem lantanowców w trakcie transformacji schwertmannitu w ferrihydryt, goethyt, lepidokrokit, akaganéit i hematyt. Należy nadmienić, że z kolei obniżenie pH, wywołane nasileniem się reakcji [1-4] (vide rozdział Środowiska wystepowania kwaśnych wód kopalnianych), powoduje rozpuszczanie wymienionych tlenków i wodorotlenków żelaza i uwalnianie do wody zaadsorbowanych wcześniej lantanowców i towarzyszących im pierwiastków. Z kolei szybkość reakcji [1-4] zależy od dopływu do zbiornika produktów wietrzenia pirytu, aktywności mikroorganizmów, temperatury, opadów atmosferycznych, nasłonecznienia, morfologii zbiornika itp. (Gammons i in., 2005a; Acero i in., 2006; Paikaray, Peiffer, 2012; Migaszewski i in., 2016, 2019). Wyniki badań dowiodły też, że obecność materii organicznej i minerałów ilastych prowadzi do zwiększenia całkowitej adsorpcji pierwiastków (Michaelides $\mathrm{i}$ in., 2010).

W kwaśnych wodach kopalnianych lantanowce występują przeważnie $\mathrm{w}$ postaci kompleksów z dominującymi jonami $\mathrm{SO}_{4}{ }^{2-}-\mathrm{LnSO}_{4}{ }^{+}, \mathrm{Ln}\left(\mathrm{SO}_{4}\right)^{2-}$ (m.in. Miekeley i in., 1992; Johannesson, Lyons, 1995), rzadziej zaś w postaci wolnych kationów $\mathrm{Ln}^{3+}$ oraz $\mathrm{Eu}^{2+} \mathrm{i} \mathrm{Ce}^{4+}$ (Leybourne i in., 2000; Fernández-Caliani i in., 2009) lub zaadsorbowanych na różnych cząstkach koloidów. Prawdopodobnie i w tym przypadku może dojść do frakcjonowania pojedynczych lantanowców, na co mogą wskazywać wysokie wartości współczynników korelacji rang Spearmana dla MREE i HREE. Na przykład w kwaśnych wodach zbiorników w Wiśniówce, Sm 0,79 - Gd 0,84 - Dy 0,86 - Lu 0,77 (Migaszewski i in., 2019). Inne kompleksy, np. fosforanowe lub fluorkowe, również mogą odgrywać znaczącą rolę w przypadku dużego stężenia tych ligandów (Wood, 1990; Gimeno Serrano i in., 2000; Migaszewski i in., 2019).

Należy podkreślić, że REE ulegają frakcjonowaniu (specjacji) w trakcie rozmaitych procesów geochemicznych, choć z uwagi na wpływ wielu zmiennych, interpretacja wyników jest trudna i nie zawsze właściwa. Większość kwaśnych wód kopalnianych wykazuje wyraźne wzbogacenie w pośrednie REE (MREE), co dokumentują ich znormalizowane profile o dachowym lub dzwonowym kształcie, z wyraźną dodatnią anomalią Eu, rzadziej Gd lub Tb (m.in. Johannesson i in., 1996; Gimeno Serrano i in., 2000; Zhao i in., 2007; Fernández-Caliani i in., 2009; Welch i in., 2009; Migaszewski i in., 2014, 2015, 2016, 2019; Lecomte i in., 2017). Eksperymenty laboratoryjne wykazały, że MREE są albo łatwiej ługowane ze skał (czy odpadów) lub też są łatwiej rozpuszczalne $\mathrm{w}$ warunkach $\mathrm{pH}$ i redoks panujących w środowiskach kwaśnych wód kopalnianych (Leybourne i in., 2000; Fernández-Caliani i in., 2009). Z kolei wyniki kilkuletnich badań prowadzonych przez autorów wskazują raczej na wpływ chemizmu wód w zbiornikach oraz obecność koloidów (lub też osadów) i ich roli w sorpcji, desorpcji, resorpcji i współwytrącaniu lantanowców, co dokumentują zbliżone profile znormalizowanych stężeń REE w górnokambryjskich skałach macierzystych Wiśniówki (wzbogacenie z LREE), przy jednocześnie całkowicie odmiennych profilach REE w kwaśnych wodach zbiorników Podwiśniówki (przewaga MREE) i Wiśniówki Dużej (przewaga HREE; Migaszewski i in., 2014, 2016, 2019).

Interesująco przedstawia się również specjacja REE w układzie woda-koloidy, choć i w tym przypadku różni autorzy uzyskali odmienne wyniki, np. według Verplancka i współautorów (2004), koloidy tlenków i wodorotlenków żelaza adsorbują przeważnie cięższe REE (HREE) niż ich lżejsze odpowiedniki (LREE). Z kolei Gammons i inni (2005b) stwierdzili zróżnicowane frakcjonowanie lantanowców w trakcie adsorpcji na minerałach w zależności od pH wody - na tlenkach i wodorotlenkach żelaza w zakresie pH 2,5-4, a na tlenkach i wodorotlenkach glinu w przedziale pH 4,5-6,0. Wyniki badań wykonanych na obszarze Wiśniówki dowiodły, że grupa lantanowców od Pr do Dy osiagała największe wartości współczynników determinacji $\left(\mathrm{R}^{2}=0,85\right) \mathrm{z}$ tlenkami i wodorotlenkami manganu (Migaszewski i in., 2016). Odmiennie natomiast zachowują się koloidy minerałów ilastych, wykazujące często podwyższoną zawartość LREE (Johannesson, Zhou, 1999).

Do interesujących należy też zaliczyć wyniki laboratoryjnych eksperymentów na spreparowanych próbkach kwaśnych wód kopalnianych zawierających Escherichia coli i Schizophyllum commune. W pierwszym tygodniu inkubacji mikroorganizmy te wykazywały wyraźne wzbogacenie w HREE, a wody jednocześnie - w LREE (Merten $\mathrm{i}$ in., 2007). Jak wspomniano, wzbogacenie kwaśnych wód Podwiśniówki w MREE $\left(\mathrm{Sm}_{\mathrm{NASC}} / \mathrm{Yb}_{\mathrm{NASC}}=1,97\right)$, a Wiśniówki Dużej w HREE $\left(\mathrm{Sm}_{\mathrm{NASC}} / \mathrm{Yb}_{\mathrm{NASC}}=0,71\right)$ świadczy o tym, że zagadnienie interakcji woda-minerały jest dalekie od rozwiązania i wymaga dalszych szczegółowych badań.

\section{WNIOSKI}

Pierwiastki ziem rzadkich znajdują coraz szersze zastosowanie w badaniach środowiska przyrodniczego. Charakterystyczne, znormalizowane profile REE, np. Gd, La czy Sm (Kulaksiz, Bau, 2013), wykorzystuje się m.in. do lokalizacji źródeł zanieczyszczeń antropogenicznych lub geogenicznych (Migaszewski i in., 2014, 2016; Soyol-Erdene i in., 2018). W przypadku kwaśnych wód kopalnianych umożliwiają one ocenę ich wpływu na sąsiadujące ekosystemy wodne (Merten i in., 2007), jak również określenie pochodzenia odpadów górniczych w hałdach lub też monitorowanie stref występowania ukrytej mineralizacji siarczkowej w trakcie eksploatacji górniczej. Oceny takiej dokonuje się na podstawie wyników analizy chemicznej odcieków i kałuż pochodzących z hałd lub wyrobisk górniczych (Migaszewski i in., 2016, 2019). Nie bez znaczenia jest stosowanie spójnej metodyki badań środowiska kwaś- 
nych wód kopalnianych, a w szczególności referencyjnych zbiorów normalizacyjnych tych samych łupków.

\section{LITERATURA}

ACERO P., AYORA C., TORRENTÓ C., NIETO J-M. 2006 - The behavior of trace elements during schwertmannite precipitation and subsequent transformation into goethite and jarosite. Geochim. Cosmochim. Acta, 70: 4130-4139.

ANDERS E., GREVESSE M. 1989 - Abundances of the elements: Meteoritic and solar. Geochim. Cosmochim. Acta, 53: 197-214.

AYORA C., MACIAS F., TORRES E., LOZANO A., CARRERO S., NIETO J.-M., PÉREZ-LÓPEZ R., FERNÁNDEZ-MARTÍNEZ A., CASTILLO-MICHEL H. 2016 - Recovery of Rare Earth Elements and Yttrium from Passive Remediation Systems of Acid Mine Drainage. Environ. Sci. Technol., 50 (15): 8255-8262.

BAKER J., WAIGHT T., ULFBECK D. 2002 - Rapid and highly reproducible analysis of rare earth elements by multiple collector inductively coupled plasma mass spectrometry. Geochim. Cosmochim. Acta, 66 3635-3646.

BAU M., DULSKI P. 1996 - Distribution of yttrium and rare-earth elements in the Penge and Kuruman Iron-Formations, Transvaal Supergroup, South Africa. Precambrian Res., 79: 37-55.

BAU M., SCHMIDT K., PACK A., BENDEL V., KRAEMER D. 2018 The European Shale: An improved data set for normalisation of rare earth element and yttrium concentrations in environmental and biological samples from Europe. Appl. Geochem., 90: 122-149.

BELLI P., BERNABEI R., CAPPELLA F., CERULLI R., DAI C., DANEVICH F., D'ANGELO A., INCICCHITTI A., KOBYCHEV V., NAGORNY S.S., NISI S., NOZZOLI F., PROSPERI D., TRETYAK V., YURCHENKO S.S. 2007 - Search for $\alpha$ decay of natural europium. Nucl. Phys., A, 789: 15-29.

BIGHAM J.M., SCHWERTMANN U., CARLSON L. 1992 - Mineralogy of precipitates formed by biogeochemical oxidation of $\mathrm{Fe}(\mathrm{II})$ in mine drainage. [W:] Skinner H.C.W., Fitzpatrick R.W. (red.), Biomineralization Process of Iron and Manganese - Modern and Ancient Environments. Cremlingen-Destedt Germany, Catena Verlag: 219-232.

BOZAU E., LEBLANC M., SEIDEL J.L., STÄRK H.-J. 2004 - Light rare earth elements enrichment in an acidic mine lake (Lusatia, Germany). Appl. Geochem., 19: 261-271.

DOŁĘGOWSKA S., MIGASZEWSKI Z.M. 2013 - Anomalous concentrations of rare earth elements in the moss-soil system from south-central Poland. Environ. Pollut., 178: 33-40.

FERNÁNDEZ-CALIANI J.C., BARBA-BRIOSO C., DE LA ROSA J.D. 2009 - Mobility and speciation of rare earth elements in acid mine soils and geochemical implications for river waters in the southwestern Iberian margin. Geoderma, 149: 393-401.

FISHER A., KARA D. 2016 - Determination of rare earth elements in natural water samples-A review of sample separation, preconcentration and direct methodologies. Anal. Chim. Acta, 935: 1-29.

GAŁUSZKA A., MIGASZEWSKI Z.M. 2018 - Extremely high levels of trace elements in aerial parts of plants naturally growing in the Wiśniówka acid mine drainage area (south-central Poland). [W:] Wolkersdorfer C., Sartz L., Weber A., Burgess J., Tremblay G. (red.), Risk to Opportunity. ICARD/IMWA 2018, Pretoria, South Africa. Proceedings, 2: 598-603. GAMMONS C.H., WOOD S.A., NIMICK D.A. 2005a - Diel behavior of rare earth elements in a mountain stream with acidic to neutral $\mathrm{pH}$. Geochim. Cosmochim. Acta, 69: 3747-3758.

GAMMONS C.H., WOOD S.A., PEDROZO F., VAREKAMP J.C., NELSON B.J., SHOPE C.L., BAFFICO G. 2005b - Hydrogeochemistry and rare earth element behavior in a volcanically acidified watershed in Patagonia, Argentina. Chem. Geol., 222: 249-267.

GARRELS R.M., THOMPSON M.E. 1960 - Oxidation of pyrite in ferric sulfate solution. Am. J. Sci., 258: 57-67.

GIMENO SERRANO M.J., AUQUÉ SANZ L.F., NORDSTROM D.K 2000 - REE speciation in low-temperature acidic waters and the competitive effects of aluminum. Chem. Geol., 165: 167-180.

GOLDBERG E.D., KOIDE M., SCHMITT R.A., SMITH R.H. 1963 Rare-earth distributions in the marine environment. J. Geophys. Res., 68 4209-4217.

GRAWUNDER A., MERTEN D., BÜCHEL G. 2014 - Origin of middle rare earth element enrichment in acid mine drainage-impacted areas. Environ. Sci. Pollut. Res., 21: 6812-6823

GROMET L.P., DYMEK R.F., HASKIN L.A., KOROTEV R.L. 1984 The "North American shale composite"; its compilation, major and trace element characteristics. Geochim. Cosmochim. Acta, 48: 2469-2482. HASKIN L.A., WILDEMAN T.R., HASKIN M.A. 1968 - An accurate procedure for the determination of the rare earths by neutron activation. J. Radioanal. Nucl. Ch., 1: 337-348.
HOUBEN G., KAUFHOLD S. 2011 - Multi-method characterization of the ferrihydrite to goethite transformation. Clay Minerals, 46: 387-395. JOHANNESSON K.H., LYONS W.B. 1995 - Rare-earth element geochemistry of Colour Lake, an acidic freshwater lake on Axel Heiberg Island, Northwest Territories, Canada. Chem. Geol. 119: 209-223. JOHANNESSON K.H., STETZENBACH K.J., HODGE V.F., LYONS W.B. 1996 - Rare earth elements complexation behaviour in circumneutral $\mathrm{pH}$ groundwaters: assessing the role of carbonate and phosphate ions. Earth Planet Sci. Lett., 139: 305-319.

JOHANNESSON K.H., ZHOU X.P. 1999 - Origin of middle rare earth element enrichments in acid waters of a Canadian High Arctic lake. Geochim. Cosmochim. Acta, 63: 153-165.

JOHNSON D.B., HALLBERG K.B. 2005 - Acid mine drainage remediation options: a review. Sci. Total Environ., 338: 3-14.

KULAKSIZ, S., BAU, M. 2013 - Anthropogenic dissolved and collo$\mathrm{id} /$ nanoparticle-bound samarium, lanthanum and gadolinium in the Rhine River and the impending destruction of the natural rare earth element distribution in rivers. Earth Planet. Sci. Lett., 362: 41-50.

KYNICKY J., SMITH M.P., XU C. 2012 - Diversity of Rare Earth Deposits: The Key Example of China. Elements, 8 (5): 361-367.

LAWRENCE M.G., KAMBER B.S. 2007 - Rare earth element concentrations in the natural water reference materials (NRCC) NASS-5, CASS-4 and SLEW-3. Geostand. Geoanal. Res., 31 (2): 95-103.

LECOMTE K.L., SARMIENTO A.M., BORREGO J., NIETO J.M. 2017 - Rare earth elements mobility processes in an AMD-affected estuary: Huelva Estuary (SW Spain). Mar. Pollut. Bull., 121: 282-291.

LEYBOURNE M.I., GOODFELLOW W.D., BOYLE D.R., HALL G.M 2000 - Rapid development of negative Ce anomalies in surface waters and contrasting REE patterns in groundwaters associated with $\mathrm{Zn}-\mathrm{Pb}$ massive sulphide deposits. Appl. Geochem., 15: 695-723.

MAKSYMOWICZ A. 2019 - Surowce Korei Północnej. Prz. Geol. 67: 11-12. MCDONOUGH W.F., SUN S.-S. 1995 - The composition of the Earth. Chem. Geol., 120: 223-253.

MCLENNAN S.M. 1989 - Rare earth elements in sedimentary rocks: Influence of provenance and sedimentary processes. Rev. Mineral., 21: 169-200.

MERTEN D., BÜCHEL G. 2004 - Determination of rare earth elements in acid mine drainage by inductively coupled plasma mass spectrometry. Microchim. Acta, 148 (3-4): 163-170.

MERTEN D., GRAWUNDER A., LONSCHINSKI M., LORENZ C., BÜCHEL G. 2007 - Rare earth element patterns related to bioremediation processes in a site influenced by acid mine drainage. [W:] Cidu R., Frau F. (red.), Water in Mining Environments, Intern. Mine Water Assoc. Symp. 2007, May 27-31, Cagliary, Italy: 233-237.

MICHAELIDES K., IBRAIM I., NORD G., ESTEVES M. 2010 - Tracing sediment redistribution across a break in slope using rare earth elements. Earth Surf. Proc. Land., 35: 575-587.

MIEKELEY N., COUTHINO DE JESUS H., PORTO DA SILVEIRA C.L. 1992 - Rare earth elements in groundwater from the Osamu Utsumi mine and Morro do Ferro analogue study sites, Plcos de Caldas, Brazil. J. Geochem. Explor., 45: 365-387.

MIGASZEWSKI Z.M., GAŁUSZKA A. 2010 - Xenotime from the Podwiśniówka mine pit, Holy Cross Mountains (south-central Poland). Mineralogia, 41(1-2): 1-7.

MIGASZEWSKI Z.M, GAŁUSZKA A. 2015 - The characteristics, occurrence and geochemical behavior of rare earth elements in the environment: a review. Crit. Rev. Env. Sci. Tech., 45: 429-471.

MIGASZEWSKI Z.M, GAŁUSZKA A. 2016 - Geochemia środowiska. Wyd. Nauk. PWN, Warszawa

MIGASZEWSKI Z.M., STARNAWSKA E., GAŁUSZKA A. 2007 Gorceixite from the Upper Cambrian rocks of the Podwiśniówka mine pit, Holy Cross Mountains (south-central Poland). Mineral. Polon., 38 (2): $171-184$

MIGASZEWSKI Z.M., GAŁUSZKA A., MIGASZEWSKI A. 2014 The study of rare earth elements in farmer's well waters of the Podwiśniówka acid mine drainage area (south-central Poland). Environ. Monit. Assess., 186: 1609-1622.

MIGASZEWSKI Z.M., GAŁUSZKA A., DOŁĘGOWSKA S., HAŁAS S., KRZCIUK K., GEBUS B. 2015 - Assessing the impact of Serwis mine tailings site on farmer's wells using element and isotope signatures (Holy Cross Mountains, south-central Poland). Environ. Earth Sci., 74: 629-647.

MIGASZEWSKI Z.M., GAŁUSZKA A., DOŁEGOWSKA S. 2016 Rare earth and trace element signatures for assessing an impact of rock mining and processing on the environment: Wiśniówka case study, south-central Poland. Environ. Sci. Pollut. Res., 23 (24): 24943-24959. MIGASZEWSKI Z.M., GAŁUSZKA A., DOŁĘGOWSKA S. 2018a Stable isotope geochemistry of acid mine drainage from the Wiśniówka area (south-central Poland). Appl. Geochem., 95: 45-56.

MIGASZEWSKI Z.M., GAŁUSZKA A., DOŁĘGOWSKA S. 2018b Arsenic in the Wiśniówka acid mine drainage area (south-central Poland) 
- mineralogy, hydrogeochemistry, remediation. Chem. Geol., 493: 491-503.

MIGASZEWSKI Z.M., GAŁUSZKA A., DOŁEGOWSKA S. 2019 -

Extreme enrichment of arsenic and rare earth elements in acid mine drainage: Case study of Wiśniówka mining area (south-central Poland). Environ. Pollut., 244: 898-906.

MURAD E. 2010 - Mössbauer spectroscopy of clays, soils and their mineral constituents. Clay Minerals, 45: 413-430.

NESBITT H.W. 1979 - Mobility and fractionation of rare earth elements during weathering of a granodiorite. Nature, 279: 206-216.

NORDSTROM D.K. 2011 - Mine Waters: Acidic to Circumneutral. Elements, 7 (6): 393-398.

NORDSTROM D.K., ALPERS C.N., PTACEK C.J., BLOWES D.W.

2000 - Negative $\mathrm{pH}$ and extremely acid mine waters from Iron Mountain Superfund site, California. Environ. Sci. Techn., 34 (2): 254-258.

ORIHASHI Y., HIRATA T. 2003 - Rapid quantitative analysis of Y and

REE abundances in XRF glass bead for selected GSJ reference rock standards using Nd-YAG $266 \mathrm{~nm}$ UV laser ablation ICP-MS. Geochem. J., 37: 401-412.

PAIKARAY S., PEIFFER S. 2012 - Abiotic schwertmannite transformation kinetics and the role of sorbed As(III). Appl. Geochem., 27: 590-597.

PLUMLEE G.S. 1999 - The environmental geology of mineral deposits [W:] Plumlee G.S., Logsdon M.J. (red.), The Environmental geochemistry of mineral deposits, Part A. Processes, techniques, and health issues. Soc. Econ. Geologists Rev. in Econ. Geol., 6A: 71-116.

POURMAND A., DAUPHAS N., IRELAND T.J. 2012 - A novel extraction chromatography and MC-ICP-MS technique for rapid analysis of REE, Sc and Y: Revising CI-chondrite and Post-Archean Australian Shale (PAAS) abundances. Chem. Geol., 291: 38-54.

POZO G., PONGY S., KELLER J., LEDEZMA P., FREGUIA S. 2017

A novel bioelectrochemical system for chemical-free permanent treatment of acid mine drainage. Water Res., 126: 411-420.

PROTANO G., RICCOBONO F. 2002 - High contents of rare earth elements (REEs) in stream waters of a $\mathrm{Cu}-\mathrm{Pb}-\mathrm{Zn}$ mining area. Environ. Pollut., 117: 499-514.

RAMSEY M.H., THOMPSON M., HALE M. 1992 - Objective evaluation of precision requirements for geochemical analysis using robust analysis of variance. J. Geochem. Explo., 44 (1-3): 23-36.

ROMERO F.M., PROL-LEDESMA R.M., CANET C., ALVARES L.N., PÉREZ-VÁZQUEZ R. 2010 - Acid drainage at the inactive Santa Lucia mine, western Cuba: Natural attenuation of arsenic, barium and lead, and geochemical behavior of rare earth elements. Appl. Geochem., 25 716-727.

SALVINI A., CATTADORI C., BROGGINI C., CAGNAZZO M., ORI G.G., NISI S., BORIO A., MANERA S. 2006 - Ir and Rare Earth's Elements determination by Neutron Activation Analysis and ICP-MS in soil samples. J. Phys. Conf. Ser., 41: 551-554.
SCHWERTMANN U., BIGHAM J.M., MURAD E. 1995 - The first occurrence of schwertmannite in a natural stream environment. European J. Mineral., 7: 547-552.

SIMÓN M., MARTIN F., ORTIZ I., GARCIA I., FERNÁNDEZ J., FERNÁNDEZ E., DORRONSORO C., AGUILAR J. 2001 - Soil pollution by oxidation of tailings from toxic spill of a pyrite mine. Sci. Total Environ., 279: 63-74.

SINGER P.C., STUMM W. 1970 - Acidic mine drainage: The rate determining step. Science, 167: 1121-1123.

SOYOL-ERDENE T.O., VALENTE T., GRANDE J.A., TORRE DE LA M.L. 2018 - Mineralogical controls on mobility of rare earth elements in acid mine drainage environments. Chemosphere, 205: 317-327.

TAYLOR S.R., MCLENNAN S.M. 1985 - The continental crust: Its composition and evolution. Blackwell Scientific Publications, Oxford. USGS 2012 - Rare Earths Statistics and Information. United States Geological Survey; http://minerals.usgs.gov/minerals/pubs/commodity/rare earths VERPLANCK P.L., ANTWEILER. R.C., NORDSTROM D.K., TAYLOR H.E - 2001. Standard reference water samples for rare earth element determinations. Appl. Geochem., 16: 231-244.

VERPLANCK P.L., NORDSTROM D.K., TAYLOR H.E., KIMBALL B.A 2004 - Rare earth element partitioning between hydrous ferric oxides and acid mine water during iron oxidation. Appl. Geochem., 19: 1339-1354. WEI Z.G., HONG F.S., YIN M., LI H.X., HU F., ZHAO G.W., WONG J.W.C. 2005 - Subcellular and molecular localization of rare earth elements (REEs) and structural characterization of yttrium bound chlorophyll a in naturally grown fern Dicranopteris dichotoma. Microchem. J., 80: 1-8.

WELCH S.A., CHRISTY A.G., ISAACSON L., KIRSTE D. 2009 Mineralogical control of rare earth elements in acid sulfate soils. Geochim. Cosmochim. Acta, 73: 44-64.

WIEDENBECK M., ALLE P., CORFU F., GRIFFIN W.L., MEIER M., OBER F., VON QUANT A., RODDICK J.C., SPIEGEL J. 1995 - Three natural zircon standards for U-Th-Pb, Lu-Hf, trace element and REE analyses. Geostandard Newslett., 19: 1-23.

WOOD S.A. 1990 - The aqueous geochemistry of the rare-earth elements and yttrium. 1. Review of available low-temperature data for inorganic complexes and the inorganic REE speciation of natural waters. Chem. Geol., 82: 159-186.

ZAWISZA B., PYTLAKOWSKA K., FEIST N., POLOWNIAK M., KITA A., SITKO R. 2011 - Determination of rare earth elements by spectroscopic techniques: a review. J. Analyt. Atom. Spectrom., 26: 2373-2390.

ZHAO F., CONG Z., SUN H., REN D. 2007 - The geochemistry of rare earth elements (REE) in acid mine drainage from the Sitai coal mine, Shanxi Province, North China. Int. J. Coal Geol., 70: 184-192.

Praca wpłynęła do redakcji 31.12.2018 r. Akceptowano do druku 11.01.2019 r. 


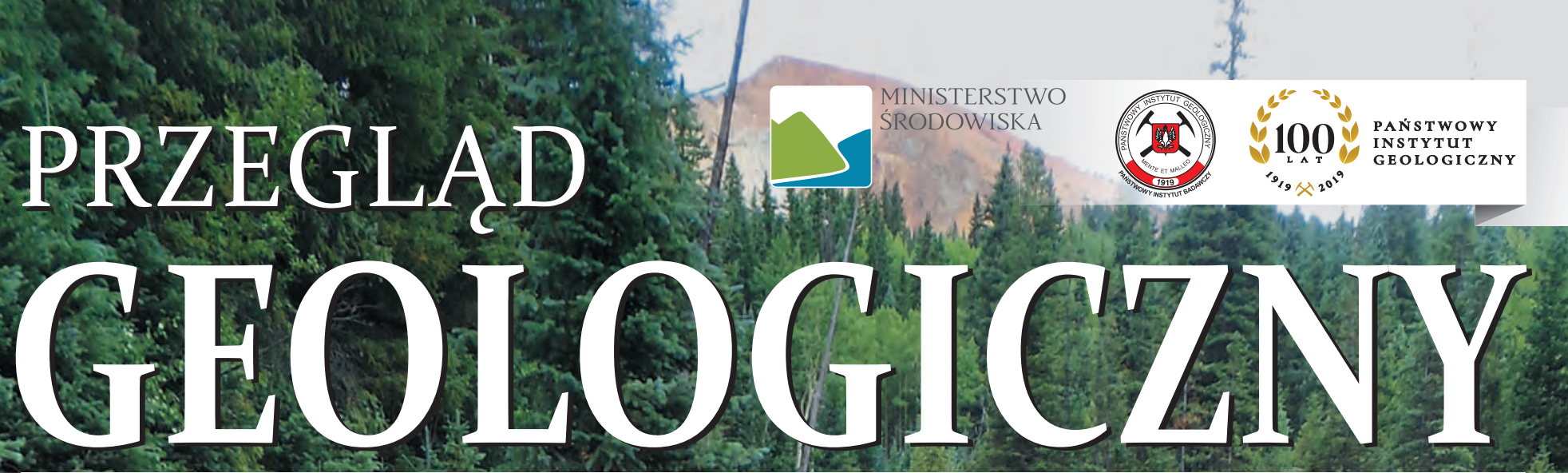

Cena 12,60 zf ( $w$ tym $5 \%$ VAT)

TOM 67 Nr2 (LUTY) 2019

Indeks 370908 ISSN-0033-2151

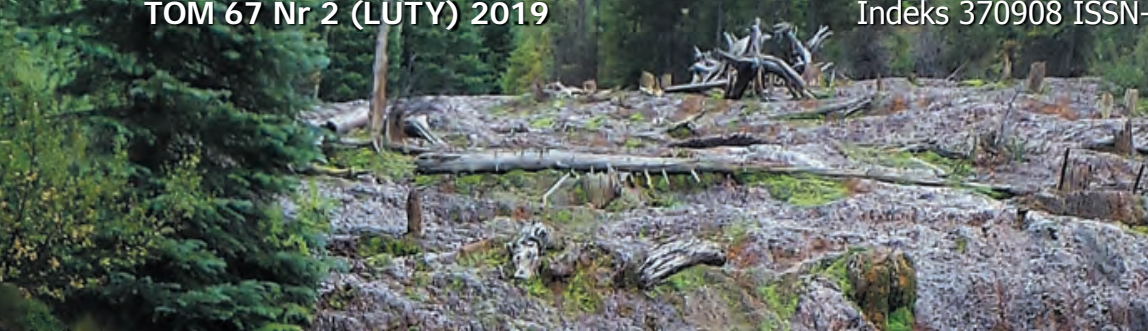

in

Whis

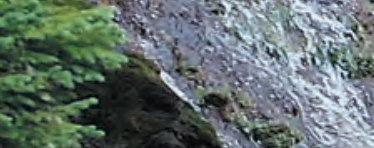

Hilstoria badań pié wriast liow promieniotwóresych W. PIG

Bhtre mining na Atlantyku - real ha pot teba cyy potrizeba realinmus?

- Pierwiastki zien rzadkich w hwaśnych wodach kopalnianych 
Zdjęcie na okładce: Red Mountain Creek z bocznymi dopływami w pobliżu drogi 550; SW Kolorado, USA (patrz artykuł Z.M. Migaszewskiego i A. Gałuszki na str. 105). Fot. Z.M. Migaszewski

Cover photo: Red Mountain Creek with side affluents near highway 550; SW Colorado, USA (see article by Z.M. Migaszewski and A. Gałuszka on p. 105). Photo by Z.M. Migaszewski 
Pierwiastki ziem rzadkich w kwaśnych wodach kopalnianych - zarys problematyki (patrz str. 105)

Rare earth elements in acid mine drainage waters; an outline of the issues (see p. 105)

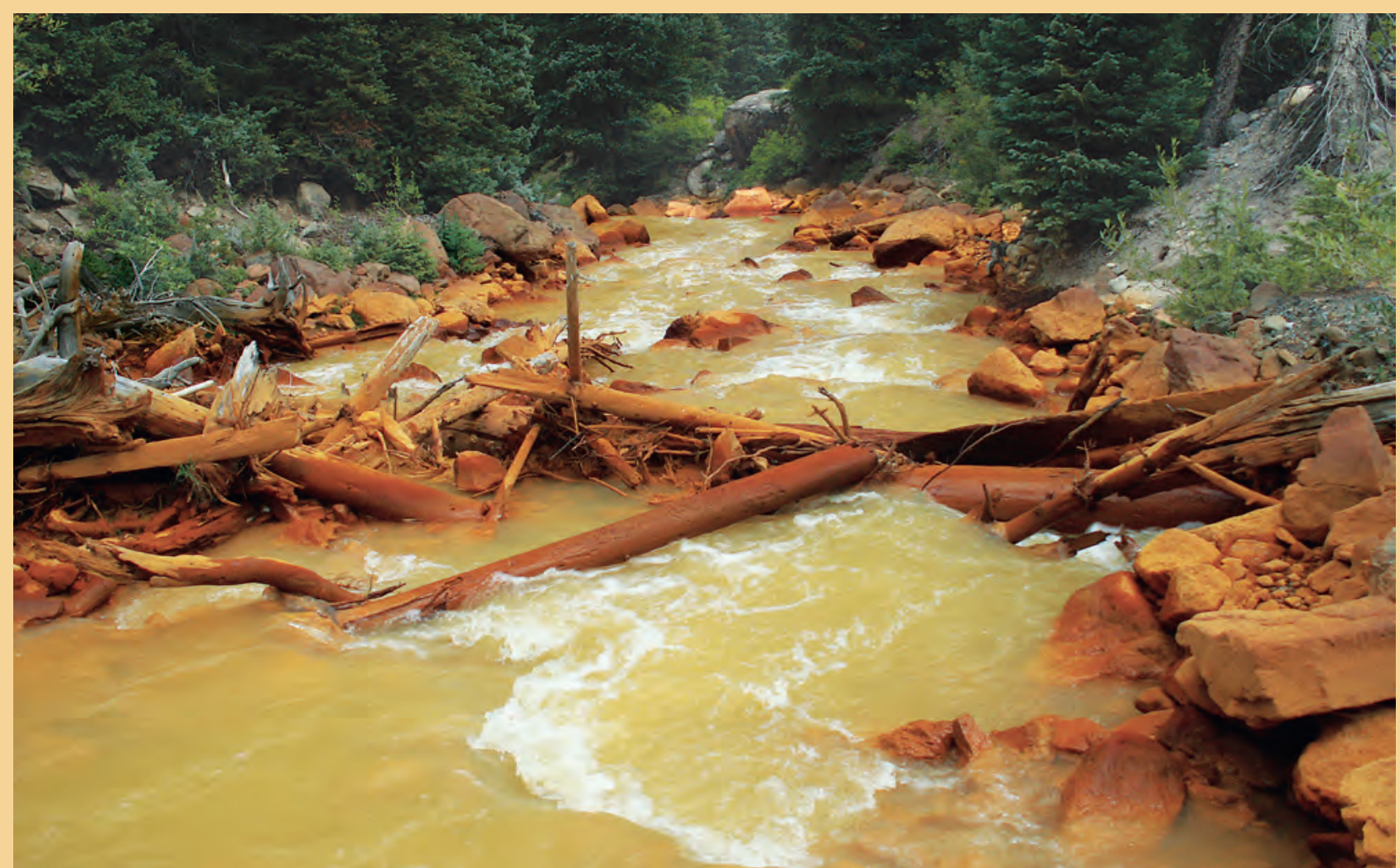

Ryc. 4. Red Mountain Creek w połowie drogi między przełęczą Red Mountain Pass a miasteczkiem Ouray (SW Kolorado, USA). Fot. A. Gałuszka

Fig. 4. Red Mountain Creek halfway between the Red Mountain Pass and a small town of Ouray. Photo by A. Gałuszka

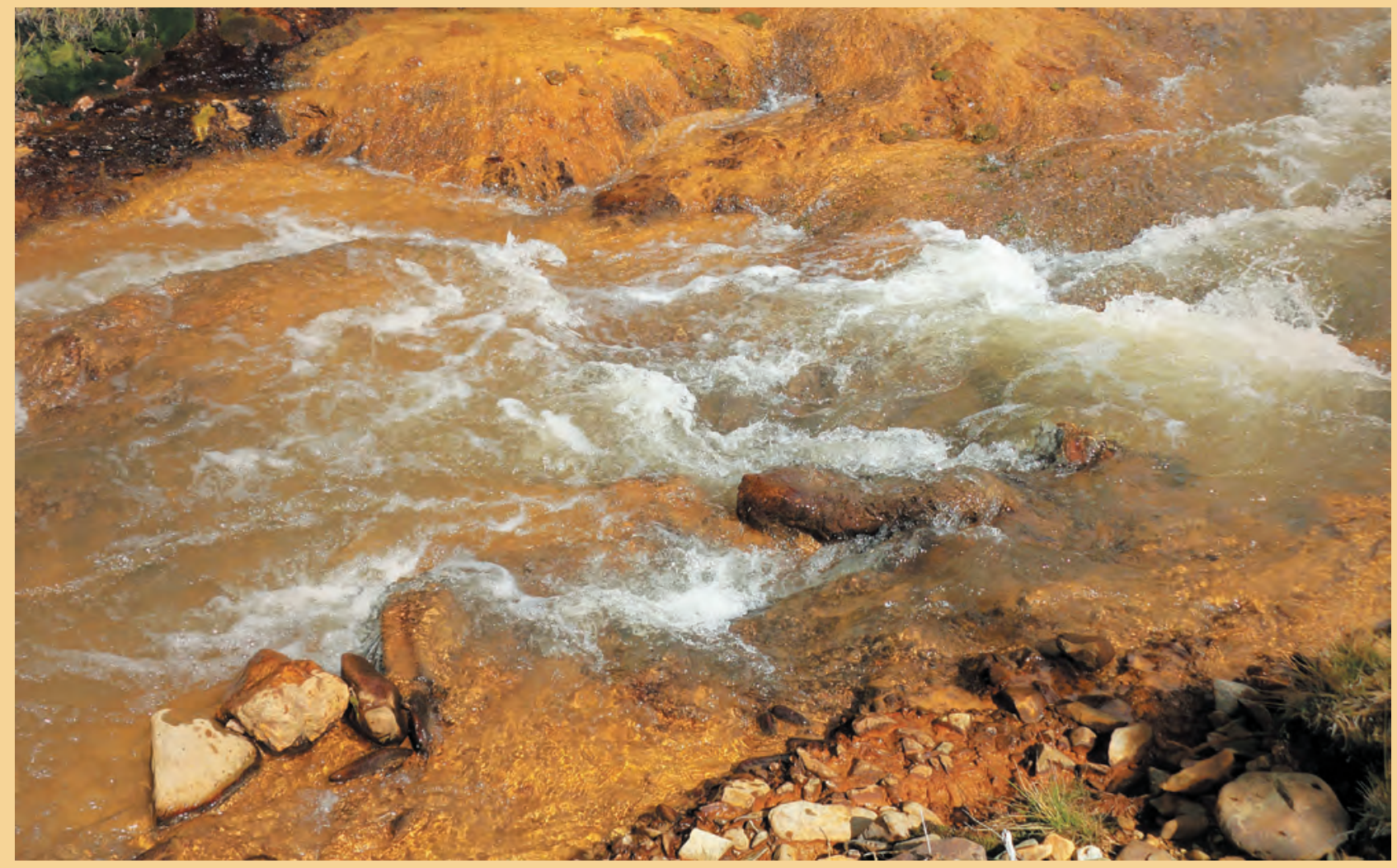

Ryc. 5. Cement Creek w pobliżu Gladstone na północ od Silverton (SW Kolorado, USA). Fot. Z.M. Migaszewski

Fig. 5. Cement Creek near Gladstone north of Silverton (SW Colorado, USA). Photo by Z.M. Migaszewski 